\title{
Encountering settler colonialism through legal objects: a painted drum and handwritten treaty from Manitoulin Island
}

\author{
RUTH BuCHANAN ${ }^{1}$
}

Osgoode Hall Law School, York University

and

JeFFERY G HEWITT2

Faculty of Law, University of Windsor, Canada

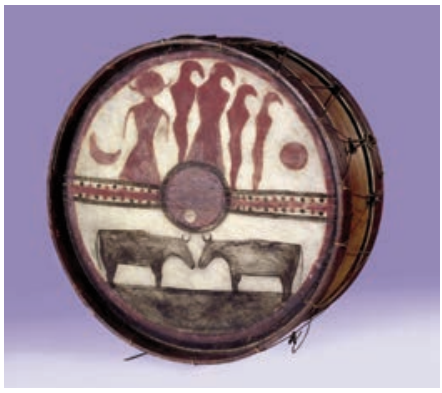

Painted drum

(C) Trustees of the

British Museum†

\begin{abstract}
The eighteenth and nineteenth centuries generated a trove of objects documenting the encounter between the Anishinaabe of the Great Lakes region and the British. Two such objects, a drum painted with Anishinaabe imagery and a treaty, handwritten by a British treaty commissioner, were created in close proximity in both time and location. This paper explores the encounter between the Anishinaabe and the British through a parallel engagement with both drum and treaty; placing them in conversation with each other. We consider the divergent paths taken by these objects by comparing the material, legal and sensory landscapes in which they were produced with their current contexts. In dialogue, the objects reveal their performative contributions to the British imperial project; one as an authorised claim to (indigenous) property, the other as (British Museum) property, displayed as artefact. Read in parallel, the treaty's assertions of authority and the drum's mute resistance interrogate the form of law itself, and the agency of law's objects.
\end{abstract}

Keywords: Indigenous Peoples; Canada; settler colonialism; treaties; Manitoulin island; Anishinaabe; intersocietal; legal objects.

$\dagger \quad<$ www.britishmuseum.org/research/collection_online/collection_object_details.aspx?assetId $=26035001$ \&objectId=536775\&partId=1

1 Ruth Buchanan is a Professor at Osgoode Hall Law School. She would like to thank Amanda Perry-Kessaris for curating the event that provoked this paper, the participants at the Legal Objects Workshop for their engagements, Jeffery G Hewitt for insightful and generous collaboration, Kerry Young for excellent research assistance, and the University of Kent and Osgoode Hall Law Schools for supporting research trips to the British Museum in London and the Archives of Canada in Ottawa.

2 Jeffery G Hewitt is an Assistant Professor, Faculty of Law, University of Windsor. He thanks Ruth Buchanan for being a patient collaborator, Kerry Young for her assistance as well as Dr Jago Cooper at the British Museum, along with his curatorial staff Cynthia McGowan and James Hamill, for caring for the painted drum, which is one of the subjects of this paper. 
The encounter of the British and the Anishinaabe peoples in the Great Lakes region during the eighteenth and nineteenth centuries has been well documented. Even so, or perhaps because of those documents, a great deal remains unsaid, and as yet unheard, about those encounters. This essay attempts a different approach. ${ }^{3}$ Rather than turning first to the texts - which after all were generated almost exclusively by the hand and in the language of the colonisers - we have chosen to ground our inquiry in the close study of two distinctive objects; both of which were produced on Manitoulin Island at a time of intensifying settlement in the region in the 1830s. The painted drum is a military snare drum of British manufacture, painted on both sides with Anishinaabe images. It was part of the collection of the British traveller Henry Christy, who visited Manitoulin Island in 1848 and bequeathed it to the British Museum some years later. The treaty is handwritten on parchment, affixed with a ribbon and seal, and signed by Treaty Commissioner Bond Head as well as the dodems of 16 Anishinaabe leaders. It is currently held in a storage facility of Archives Canada in Gatineau, Quebec.

Each of these items is, in our analysis, both an object of and evidence concerning the legal encounters between the Anishinaabe people who have been residing in the region for millennia and the more recently arrived British settlers. They are material traces of times in which the Anishinaabe and the British came together in that territory. They each bear the marks of both peoples, and they each testify in their own ways to the nature of those encounters. They have both been carefully stored and preserved, but to quite distinct ends - which speaks to the differences in the ways in which they have been (mis)understood. The treaty, after all, is legible to Canadian legal historians and lawmakers as an historical legal document. The drum is also legible as a legal object to those who are educated in the language and culture of the Anishinaabe peoples, and yet, unlike the treaty, which has remained in the possession of the government of Canada, the drum has been for more than 150 years kept far from the communities whose law it embodies. Our purpose in setting them beside each other in this article is, in the first instance, to highlight this discrepancy, so that legal academics and historians might begin to more readily perceive the many sources of Anishinaabe law. ${ }^{4}$ Secondly, in focusing attention on the handwritten document that is identified by Archives Canada as Treaty 45 or the Manitoulin Island Treaty (1836), rather than the text as such, we are seeking to bring to the fore the material and performative aspects of the historical arrogation of legal authority over the island. We have in past work observed the tendency among legal scholars to over-valorise the written text as the source of law's authority, with the consequence that the material and the performative aspects of both western and indigenous legal orders end up being minimised, or overlooked altogether. ${ }^{5}$ In the complex ravelling and unravelling of relations among Indigenous Peoples, settlers and territories in the North American continent, legal objects have played a critical role, the significance of which has yet to be appreciated by legal scholars.

In the essay that follows, we will consider the role that both the drum and the treaty might have played in the imposition of British imperialism on the North American

3 We have a shared interest in the study of legal objects, which first found voice in R Buchanan and J Hewitt 'Treaty Canoe' in J Hohmann and D Joyce (eds), International Law's Objects (Oxford University Press 2018). One strand of Ruth's ongoing research has explored the relations between experience, affect and legal pluralism; while a facet of Jeffery's research examines sources and forms of law of Indigenous Peoples in what is now known as Canada - particularly Anishinaabe and Cree laws.

4 See, for example, L Simpson, 'Looking after Gdoo-naaganinaa: Precolonial Nishnaabeg Diplomatic and Treaty Relationships’ (2008) 23(2) Wicazo Sa Review 29-42.

5 Buchanan and Hewitt (n 3) and Peter Goodrich (2009) 'Screening Law' 21 Law and Literature 3. 
continent. Our approach both acknowledges the agency of these objects and seeks to generate a productive dialogue between them. To that end, we contemplate each object on its own terms as a site of law-making, and then reflect on how their juxtaposition might help us to better understand the long history of relations between Anishinaabe Peoples, the British Crown and the Canadian state.

\section{A painted drum 6}

Within the museum's empire of sight, objects are colonized by the gaze. ${ }^{7}$

The painted drum is currently on display in the 'North America' room in the British Museum, behind glass, situated among a small collection of Anishinaabe artefacts from approximately the same region and time frame (early 1800s). The entry for the drum in the British Museum online catalogue is brief, but one can learn that it was part of the collection of the British traveller Henry Christy, who likely visited Manitoulin Island in $1856 .{ }^{8}$ Christy's extensive collection, including a substantial number of objects from North American indigenous communities, was bequeathed to the British Museum on his death in 1865.?

In the display, the drum stands out as an intriguing and somewhat mysterious object. It is clearly a military snare drum of British manufacture that has been painted over with Anishinaabe images. A central circle and horizontal line divide the surface of the drum. Above the line are a series of five figures, with a crescent moon on the left and a circle (sun or moon) on the right. The figure to the farthest left appears human, while the other figures are more birdlike. Below the line are two horned wood buffalo - facing inward. The composition of images on the drum, according to Alan Corbiere and Ruth Phillips, 'communicates a fundamental sense of the order and balance of powers and beings in the Anishinaabe cosmos' and was 'shown to be of particular significance in a conversation held by Alan Corbiere in December 2004 with an elder from the Wikwemikong Unceded Indian Reserve on Manitoulin Island'. ${ }^{10}$

This drum speaks to us as a legal object in several different ways - including the roles that it likely played in British military

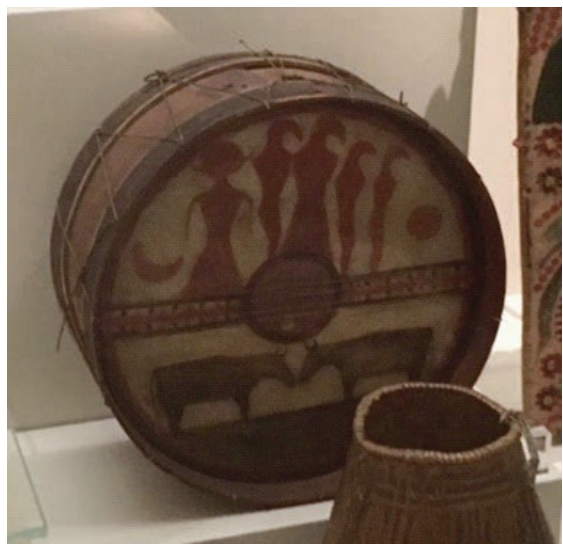

Figure 1: Drum from Manitoulin Island, around 1846, on display at the British Museum Source: J Hewitt, 2017

6 In September 2016, together we found ourselves at a gathering of colleagues involved in GRASAC - Great Lakes Research Alliance for the Study of Aboriginal Arts and Culture - and, through various discussions, found ourselves drawn to this particular drum from Manitoulin Island as an object of law.

7 C Claessen and D Howes, 'The Museum as Sensescape: Western Sensibilities and Indigenous Artifacts' in E Edwards, C Gosden and R Phillips (eds), Sensible Objects: Colonialism, Museums and Material Culture (Bloomsbury 2006).

8 <www.britishmuseum.org/research/collection_online/collection_object_details.aspx?objectId $=536775 \&$ partId=1>

9 The precise extent of the Christy Collection in 1865 is unknown, but one account suggests it numbered over 1000 ethnographic items. See <http://era.anthropology.ac.uk/Era_Resources/Era/Pitt_Rivers/musantob/ histmus6.html\#anchor63901>. See also William Jerome Harrison, 'Christy, Henry' in Leslie Stephen, Dictionary of National Biography 10 (Smith, Elder \& Co 1887) 295-6.

10 Alan Corbiere and Ruth B Phillips, 'A Dehe'igan (Drum) from Manitoulin Island' (Native Drums) $<$ www.native-drums.ca/index.php/Scholars/Deheigan?tp $=a \& b g=1 \& \ln =\mathrm{e}>$. 
discipline, in the Anishinaabe legal order, ${ }^{11}$ the intersections and encounters between those legal orders in the mid-nineteenth century and today. In its qualities of mobility and mutability, the drum reminds us that we need to approach it on its own terms. In the Anishinaabe legal order, drums are powerful legal objects that authorise those who are responsible for them to perform certain roles or ceremony. While we do not know the particulars of this drum's story, who it belonged to or how it came into the possession of Henry Christy, this erasure does not mean that the drum can only be seen as the museum sees it, as a static remnant of a long dead past. We encounter the drum as a powerful object that continues to have strong connections to a place, a community and a legal order that have been continuous and are continuing. ${ }^{12}$

The drum calls upon us to consider the particular 'law-scapes' in which it was entangled - the law-scape of the colonial British administration of the 1810s and 1820s and the law-scape of the Anishinaabe peoples of Manitoulin Island of the same time frame. But the drum also invites us to think about those law-scapes as also soundscapes - to consider the rhythms of those peoples and their relationships of the time. ${ }^{13}$ In thinking through the relations between law and sound it is important to attend to both the physical/material as well as the cultural aspects of a soundscape - that is, it is both a world and a culture constructed to make sense of that world. ${ }^{14}$ It follows that the soundings of the British military drum on Anishinaabe territory and its soundings as an Anishinaabe drum would have resonated quite differently. In thinking about the drum's sounding out of the law in these different ways, in this paper, we are engaged in a consideration of 'acoustic jurisprudence'. According to James Parker, acoustic jurisprudence is 'an orientation towards law attuned to questions of sound and listening'. ${ }^{15}$ Encountering the drum not as an artefact but as a legal object, we suggest, helps us to reveal something of the 'diverse ways in which law and sound are deeply and necessarily bound to each other'. ${ }^{16}$ 'This is not a simple or straightforward task, however. One challenge for a material historian of legal culture is to try to make sense of the object that has been disembedded from its time, its place, its use, its peoples. In our case, we must also make sense of a sound-making object that has been muted.

The drum, in its current walled-off silence, thus also compels a reflection on the 'empire of sight' that is constitutive of the contemporary museum and the ongoing legal, social and cultural orderings that uphold that regime. This variety of overlapping roles and potentialities that reside in or are possessed by the drum also suggest to us a particular avenue of engagement with its thingness - what it has to teach us goes beyond an 'object lesson' in the sense of it having a fixed or unitary meaning or symbol. When we spoke about the drum in its presence, in the North American room of the British Museum in

11 For discussion on Anishinaabe law, see John Borrows, Freedom and Indigenous Constitutionalism (University of Toronto Press 2016); Heidi Stark, 'Respect, Responsibility, and Renewal: The Foundations of Anishinaabe Treaty Making with the United States and Canada' (2010) 34(2) American Indian Culture and Research Journal 145-64; and Leanne Betasamosake Simpson, 'Land as Pedagogy: Nishnaabeg Intelligence and Rebellious Transformation' (2014) 3(3) Decolonization: Indigeneity, Education and Society 1-25.

12 On the damage done by displacement of such objects from their points of origin, see Sara Keenan, 'The Gweagal Shield' (2017) 68(3) NILQ 283-90 (this volume). It's important to note, however, that in the case of the drum there is no information available regarding its transfer to Christy, nor any suggestion that its removal from the territory was illegal according to Anishinaabe law.

13 'The soundscape is always also a lawscape. Our sonic worlds resonate with law at every level.': James Parker, 'Acoustic Jurisprudence: Law and the Long Range Acoustic Device' (2015) Law, Culture and the Humanities $1-17,3$.

14 James Parker, 'The Soundscape of Justice' (2011) 20 Griffith Law Review 962.

15 Parker (n 13) 7.

16 Ibid. 
front of a small group of legal academics participating in the Legal Object workshop project, we sought to address it in some way, on its own terms. As part of our presentation, we had been asked to distribute a trace of the object to the participants. Without more explicit instructions, we interpreted that to mean an invitation to materially reproduce, in portable form, a reflection of the essence of our object. ${ }^{17}$ As the drum was originally a British military drum painted with Anishinaabe cosmological representations - an intersocietal object - we opted to represent it with Britishsourced glass jam jars with tin lids, in which a handful of wild rice grown in Anishinaabe territory was contained. Though the drum was on display behind glass and therefore unable to be sounded, when our trace was shaken, the rice against the tin lid sounded like the snare of the drum, thus allowing

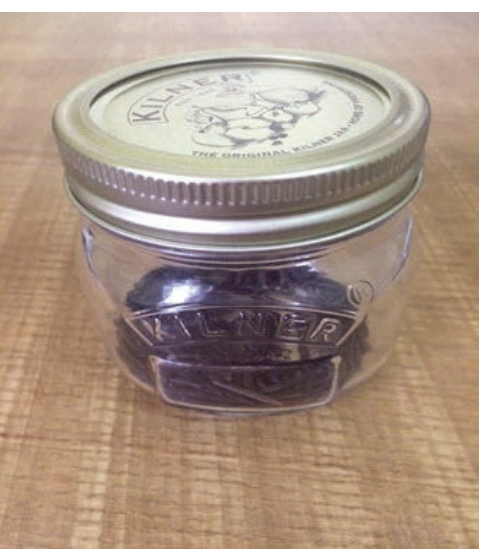

Figure 2: Drum 'trace': Kilner glass jar and wild rice from Rice Lake Source: R Buchanan, 2017 participants to collectively imagine (and reproduce) the soundscape of the drum itself. Though somewhat restrained, the distribution of jars at the event did provoke a smattering of soundings in the museum and, we hope, afterwards, as participants took the 'trace' with them to their homes and offices.

Continuing to address the drum on its own terms in the context of this essay calls for us to not only give it voice, but also to provide context by detailing what we know of its travels from the British to the Anishinaabe and back, its various uses in those locations, its current situation and the potential it represents.

\subsection{LOCATING THE DRUM: LANDSCAPES/LAW-SCAPES}

What might be said in particular about the place of this drum in the law-scapes that it moved through and sounded upon? There is much we can only speculate about - where it may have travelled, who made it and for what purposes, to whom it was gifted and on what occasions, and how it eventually arrived in the British Museum's vast collection of North American indigenous objects, which numbers about 100,000. But there are a few things that can be noted.

Thinking of it first in its incarnation as a military snare drum, we are reminded of the ongoing armed conflicts in the Great Lakes region that extended beyond the time of what is known as the Seven Years War (1755-1762) right through to 1815 - so extensive that they are called by some historians the 60 Years War. ${ }^{18}$ We know that the snare drums are valued highly by the military - drummers were paid more than regular infantry and they

17 Amanda Perry-Kessaris has described the invitation to produce a 'trace' in terms of a type of 'modelling' of the object. See the introduction to this special issue, 'The Pop-Up Museum of Legal Objects Project: An Experiment in "Socio-legal Design" (2017) 68(3) NILQ 225-44. While we don't disagree with that description, it is important to observe that, as we did not come to the project from a 'design' perspective, this is not how we interpreted what was at the time an essentially 'mysterious' invitation issued to a pair of law professors. As both the hybrid origins and the use of our object were important to our analysis, we sought to replicate those aspects in the 'trace'.

18 For an in-depth analysis and context of the interactions between the French, British and Indigenous Peoples during this time period, see James Laxer, Tecumseh and Brock: The War of 1812 (House of Anansi 2012). 


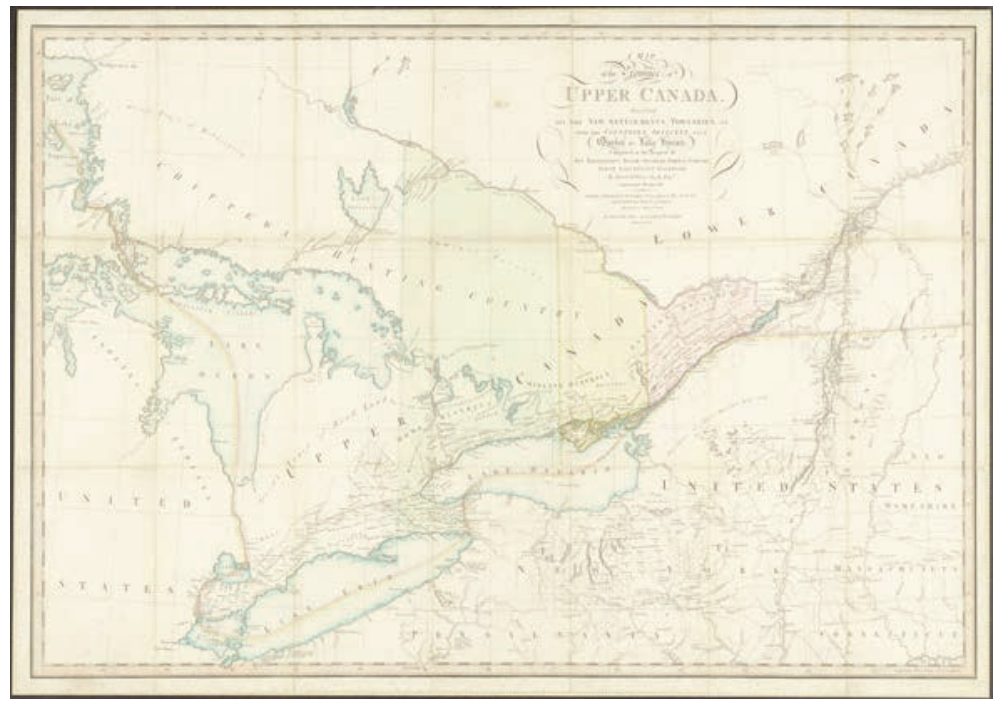

Figure 3: A Map of the province of Upper Canada, showing Manitoulin Island (yellow land mass in the top shore of Lake Ontario), Ontario, circa 1800, Canada

Source: Archives Canada

were in high demand. ${ }^{19}$ Drums were necessary to military discipline - both on and off the battlefield. In the smoke and confusion of battle, sound was a more reliable conveyer of information and discipline than sight. ${ }^{20}$ Off the battlefield, the daily routines of military life were tapped out on the drums. Notably, drummers were also frequently the individuals called upon to administer corporal punishments (which in the British military was usually flogging). On occasion, drum rolls also dramatically accompanied these public displays of authority.

While the fur-trading posts to the north were largely removed from the epicentres of military conflicts, they were also connected in that they served both military and commercial functions. We know from the work of historian and musicologist Daniel Laxer that military musical instruments made their way through the trading-post circuit and, in that context, were used for recreation or display. ${ }^{21}$

How the drum came to the Anishinaabe and what meanings it carried at that time is unclear. It might have been viewed as a trophy of war, not unlike flags or uniforms. It might have been traded for - or received as a gift. We know that there was an annual gathering on Manitoulin Island at the time, where peoples from around the region gathered and met with colonial authorities for a distribution of gifts. A very similar drum was sketched by the painter Paul Kane about 10 years previously on Manitoulin Island. This gathering is likely also the place where it was acquired by the collector Henry Christy during a trip he made in 1856. It was received by the British Museum only a few years later as part of the Christy bequest. Manitoulin Island was at the time and still remains contested land. The Manitoulin treaties were entered into in 1836 - but they were deeply

19 Daniel Laxer, 'Drums, Bugles and Bagpipes in the Seven Years War' (Early Canadian History 2016) <https://earlycanadianhistory.ca/2016/02/22/drums-bugles-and-bagpipes-in-the-seven-years-war>.

20 Daniel Laxer, Listening to the Fur Trade: Sound, Music and Dance in Northern North America, 1760-1840 (unpublished dissertation, University of Toronto 2015) 116.

21 Ibid 109. 
contested almost immediately and the territory, and many adjacent territories, were subject to an ongoing legal dispute. What is uncontested is that, for the British Crown, as we will discuss in the next section, the engagement with the Anishinaabe on Manitoulin Island was about gaining possession of lands and resources. For the Anishinaabe, however, the treaties were about relationships that made way for the sharing of lands and resources - but not transfer of ownership.

Treaties are a solemn form of contract. ${ }^{22}$ To be binding, Canadian contract law requires a meeting of the minds. That is, at its most basic, an agreement, to be enforceable, requires some degree of mutual comprehension, evidence of which, in the case of the historical treaties, is very limited and difficult to obtain. Studying evidence of material culture that was in existence at the time of the Manitoulin treaties - such as the drum - offers us a rich line of inquiry in which we might view the perspectives of the Crown and the Anishinaabe peoples in relation to those treaties. ${ }^{23}$ For example, the Manitoulin Island drum contains imagery of transformation and is illustrative of the Anishinaabe view that land is a connection between the sky and underworld versus the Crown's view of land as a possession to be deeded and divided, bought and sold. From the Anishinaabe perspective, as evidenced by the painting on the drum, the Crown's view that land, like drums and other objects, are possessions to be collected and displayed as a signal of imperial wealth and power, is impossible to comprehend.

\subsection{LISTENING FOR THE DRUM: SENSORY LANDSCAPES AND THE COLONIAL (TIN) EAR 24}

Perhaps our relationship to things has what might be called a musical quality, which we forget at our peril. Music has, of course, routinely been degraded as evolutionarily peripheral and even non-adaptive but it keeps stubbornly reappearing as a quality we cannot reduce to something else, including the history of evolution. Perhaps the aesthetic quality of things has the same kind of resonance, one that can be ignored but only with dire consequences for the power of our explanations. Things may not just talk to us, sometimes they sing. ${ }^{25}$

The ways we 'make sense' of the world implicate not only an epistemic but a phenomenological orientation in relation to a particular sensorium - our material surrounds and the ways we engage in them are relational and in process. Instead of

22 For a more in-depth discussion on treaties as contracts in what is now known as Canada between the Crown and various Indigenous Nations and legal obligations arising therein, see Michael Asch, On Being Here to Stay: Treaties and Aboriginal rights in Canada (University of Toronto Press 2014); see also Brian Slattery, 'The Hidden Constitution: Aboriginal Rights in Canada' (1984) American Journal of Comparative Law 361-91.

23 Stark (n 11).

24 As an example of law's seeming inability to attune itself to various sensory landscapes - such as music - in Delgamuukw v British Columbia [1991] 5 CNLR 5, 79 DLR (4th) (BCSC), Chief Justice McEachern was asked to listen to an elder singing a song as evidence. Justice McEachern was resistant. The trial transcript reads as follows: 'Chief Justice Allan McEachern: I don't want to be skeptical, but to have witnesses singing songs in court is, in my respectful view, not the proper way to approach this problem. Mr. Grant: Well, my Lord, with respect, the song is what one may refer to as a death song. It's a song which invokes the history of and the depth of the history of what she is telling. McEachern: I have a tin ear, Mr. Grant, so it's not going to do any good to sing it to me.' Though ultimately overturned by the Supreme Court of Canada in Delgamunkw v British Columbia [1997] 3 SCR 1010, when writing his judgment against the indigenous claimants, Chief Justice McEachern noted his 'judicial embarrassment' at having a song sung in his courtroom. By way of response, the Gitkisan and Wet'suwet'en communities (claimants) erected a totem pole explaining the history of the case. Capping the totem pole is a figure representing the likeness of Justice McEachern to which the carvers attached a large ear made of tin. For more on the disconnection between sensory landscapes and Canadian law's resistance to indigenous laws, see Borrows (n 11).

25 Nigel Thrift, 'Afterword' in D Hicks and M C Beaudry (eds), Oxford Handbook of Material Culture Studies (Oxford University Press 2010) 657. 
thinking of ourselves as subjects and the things we interact with as 'objects', we might think as makers or users do - what is this thing 'for', or what does this (drum) 'want'? This approach finds a great deal of resonance in relation to Anishinaabe understandings of material culture, in which objects are generally considered to have particular sorts of 'agency' emanating from their attributes, their relation to a particular individual, family or community, and/or their particular origin or use. ${ }^{26}$ Anishinaabe objects may want to be feasted, smudged, sounded, even allowed to deteriorate or decay.

In its location in the British Museum, the drum sits silently behind glass, among an assortment of other once useful objects, carefully arranged according to a foreign logic. It is helpful to note here that this is a relatively recent development for, in the nineteenth century, people touched and held and sounded museum objects routinely. This focus on 'conservation' as 'preservation' is only one of many possible ways one might imagine engaging with the material culture of the past. That is a more general point. Specifically, in relation to this drum, we think one needs as much as possible to take into consideration an Anishinaabe worldview/orientation and, importantly, Anishinaabe law. As Ruth Phillips says:

When an elder lifts up a moccasin or a mask in a museum storeroom and begins to sing a song or recount a story, we realize the unique potential of museum objects to trigger memories of and offer access to aesthetic and cognitive systems that are not, in the first instance, visual, but have to do, rather, with hearing, touching, smelling, or tasting. ${ }^{27}$

The idea of a law-scape that we've been using here goes well beyond the 'meaning' or 'cultural' specificity of a legal order to connect with this insight about how sensory landscapes are variable across cultures and time periods and constituted in large measure in and through the things or technologies that we interact with. The ways in which the various senses are ordered, valued, utilised, relied upon or subordinated is not given or static. The 'empire of sight' in the museum needs to be provincialised, so that the place of the other senses might be ascertained. The drum offers a mute challenge to the museum's gaze. In the presence of the drum, we took up that challenge when we distributed jam jars with wild rice among the participants of the workshop and encouraged them to shake them, recreating the sound of a snare drum through the snapping of the rice grains against the tin lids. In this paper, in setting our engagement with the drum alongside a similar engagement with the handwritten treaty as a legal object, we seek to extend that challenge to the very foundation of the colonial legal order.

\section{A handwritten treaty}

Legal scholars tend not to consider the documents they spend their days interpreting their tools of the trade, as it were - as things in themselves. ${ }^{28}$ Others, such as historians, however, might consider documents as evidence necessary to contextualise past worlds. For many disciplines, including law, the influence of material cultural is undeniable. As Leonie Hannan and Sarah Longair stated:

Material culture frames all of our actions and experiences and is constitutive of them. Material culture sheds light on our production and consumptions of goods, our power relations, social bonds and networks, gender interactions,

26 For more on personhood and agency of objects, see M Matthews, Naamiwan's Drum: The Story of a Contested Repatriation of Anishinaabe Artefacts (University of Toronto Press 2016), ch 5, 103-38.

27 Ruth B Phillips, 'Re-placing Objects: Historical Practices for the Second Museum Age' (2005) 86(1) Canadian Historical Review 83-110, 97.

28 See Annalise Riles (ed), Documents: Artifacts of Modern Knowledge (University of Michigan Press 2006). 
identities, cultural affiliations and belief. Material culture communicates all kinds of human values, from the economic or political to the social and cultural. ${ }^{29}$

Taking an artefactual approach to legal documents jolts us out of the realm of textual analysis, and invites us to consider the circumstances of both a document's production and use, as well as its materiality and the light it might shed on the power relations between the Anishinaabe and the Crown. As Genevieve Painter notes, documents 'bring things into being, initiate relations among people and create and maintain bureaucratic hierarchies'. 30 Attending to a document as an artefact, according to Painter, involves 'a consideration of the document's agency, its materialities, its conduct in relation to people and institutions, and its movement within and between places, bureaucracies and archives'. In her introduction to the edited collection Documents: Artifacts of

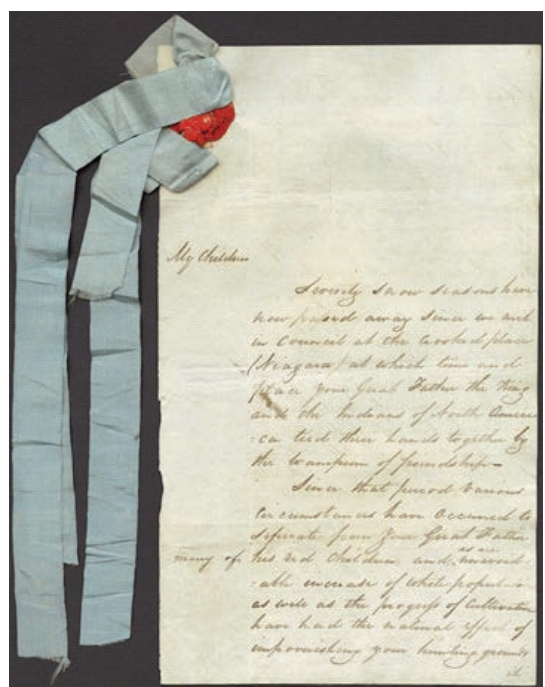

Figure 4: Manitoulin Island Treaty, 1836 front page

Source: Archives Canada Modern Knowledge, Annalise Riles observed that the turn to the examination of the formal and aesthetic properties of documents comes about in part 'as a response to the instrumentalization of documents and also to their treatment as mere texts to be read'. ${ }^{31}$ Similarly, our interest in encountering the treaty as a 'legal object' emerges from a concern with the limits of the textual or representational paradigm. We are interested in 'questions of form in the uses of formal and aesthetic properties of documents' as well as the question of 'how attention to document form might engender a rethinking of the document's instrumental and informational purpose'. 32

To begin with first impressions, the document in question is visually stunning. Long strands of pale blue ribbon flow from a round bond of sealing wax affixed in the upper left corner - the wax still as bright as the red paint of the drum, though the depth of the impressions has been smoothed away with age. The ink once dark is now a burnished brown. The treaty text is handwritten in a tight, angled and evenly spaced cursive script on a thick parchment. It contains a few small amendments in Bond Head's hand added in the margins. The text flows from the first page on to the second. On the second page is found the Treaty Commissioner Bond Head's signature in the same looping cursive handwriting as well as the dodems of 16 Anishinaabe leaders hand-drawn in a different colour pen. The document is currently held in a storage facility of Archives Canada in Gatineau, Quebec. and is seen by appointment only.

29 Leonie Hannan and Sarah Longair, History through Material Culture (Oxford University Press 2017) 1.

30 Genevieve Renard Painter, 'A Letter from the Haudenosaunee Confederacy to King George V: Writing and Reading Jurisdictions in International Legal History' (2017) 5 London Review of International Law 7-48, 15.

31 Riles (n 28) 18.

32 Ibid 19. 


\subsection{Situating THE TREATY IN THE CIRCUMSTANCES OF ITS PRODUCTION}

As already noted, the painted drum was at one time located on Manitoulin Island, in relation to which there were two treaties signed - in 1836 and 1862. The drum was likely painted contemporaneously with the first of these treaties, prior to Christy acquiring it circa 1856. Thus, we focus on the 1836 treaty ('the treaty'), which is currently housed at Library and Archives Canada. ${ }^{33}$ In contrast with the drum, much more detail is known about the treaty's history. The treaty was proposed by the then Lieutenant-Governor Francis Bond Head who sought to place all Indigenous Peoples in what is known as Upper Canada (now the province of Ontario) on to Manitoulin Island, in order to make way for the growing settler population in the region. Bond Head wrote to his superiors of his proposed experiment:

It is evident to me that we would reap a very great benefit if we could persuade these Indians, who are now impeding the progress of civilization in Upper Canada, to resort to a place possessing the double advantage to being admirably adapted to them ... and yet in no way adapted to the White population. ${ }^{34}$

Bond Head was frustrated by the Indigenous Peoples' persistence in continuing to live on their own lands and practise their culture and laws rather than follow the settlers into an agrarian existence. In his dissertation, law professor John Borrows reveals the treatymaker's mindset through the following passage from a letter written by Bond Head:

So long as we were obtaining possession of their country by open violence, the fatal result of the unequal contest was but too easily understood; but now that we have succeeded in exterminating their Race from vast regions of land, where nothing in the present day remains of the poor Indian but the unnoticed bones of his ancestors, it seems inexplicable how it should happen, that even where the race barely lingers in existence, it should still continue to wither, droop, and vanish before us like Grass in the Progress of the Forest in flames. 'The Red Men,' lately exclaimed a celebrated Miami Cacique, 'are melting like Snow before the Sun!'

Whenever and wherever the two races come in contact it is sure to prove fatal to the Red man. However bravely for a short time he may resist our bayonets and fire arms, sooner or later he is called upon by death to submit to his decree ... in short our philanthropy, like our friendship, has failed in its professions. ${ }^{35}$

As part of the effort to secure approval for the treaty, this communication from Bond Head to Lord Glenelg reveals his objectives were twofold: first, to further the colonialist agenda of assimilation; and, second, to move the Anishinaabe to lands of less interest to settlers where the Anishinaabe might continue in their ways. It is clear that, given Bond Head's views about the Indigenous People, the treaty was about land and extinguishment in favour of the settler population and a means to silence Indigenous Peoples in the same way the drum was silenced as an object.

33 For more on the history of the Manitoulin treaty, see, Robert J Surtees, Treaty Research Report: Manitoulin Island Treaties (Treaties and Historical Research Centre, Indian and Northern Affairs Canada 1986).

34 Robert J Surtees, Indian Reserve Policy in Upper Canada 1830-1845 (Carlton University 1966) 42, cited in John Borrows, Traditional Use, Treaties, and Land Title Settlements: A Legal History of the Anishinaabe of Manitoulin Island (unpublished dissertation, Osgoode Hall Law School 1994) 107.

35 PAC RG 10, Vol 391, Bond Head to Glenelg, 20 November 1836. See also Borrows (n 34) 96, fn 248. 


\subsection{VISUAL AND AUDITORY DIMENSIONS OF THE TREATY'S PERFORMANCE OF LEGAL AUTHORITY}

When we visited the Archives Canada preservation and storage facility in Gatineau Quebec for our appointment to view the treaty, we were presented with the document carefully preserved between sheets of paper and cardboard and housed in a box. We were given gloves to wear when handling it. Since it became part of the collection at Library and Archives Canada, we are the only ones who have sat with the treaty in its original form - though the record showed some years ago it was lent for a limited time to a museum display on Manitoulin Island. The handwriting was difficult to decipher - we found we had to read it out loud to make sense of it. As we did, we were struck by the oratorical quality of the prose, particularly resonant in the opening passage, which speaks to broken promises dating back to the Royal Proclamation of 1763 and the subsequent treaty at Niagara of $1764:{ }^{36}$

Seventy snow seasons have now passed since we met council at the crooked place (Niagara) at which time and place your Great Father the King and the Indians of North America tied their hands together by the Wampum of friendship.

Since that period various circumstances have occurred to separate from your Great Father many of his red children, as well as the progress of cultivation, have had the natural effect of impoverishing your hunting grounds it has become necessary that new arrangements should be entered into for the purposes of protecting you from the encroachment of the whites.

We marvelled at a text that could boldly declare the necessity of 'new arrangements' as a thinly veiled rationale for pilfering more land. Though we struggled with the text of the treaty, it is not our objective here to engage with its textual content as such. The effort required to read it, however, led us towards a consideration of the treaty as having originated in a speech, and from there, to thinking about the document itself as a performance of legal authority.

With its blue ribbon, red wax, ink and paper, the treaty is a visual performance. Through narrative carefully chosen by Bond Head, the treaty - like the painted drum - is also a sound-scape of law. Bond Head writes of the 'Great Father' and 'his Red Children' as illustrative of the treaty-maker's worldview of the power dynamic between the Crown and the Anishinaabe. The authoritative voice resonated as we read the treaty both aloud and silently. The text is a formidable performance of imperialism. Indeed, the genesis of the treaty was rooted in performance. In August of 1836, Bond Head addressed a gathering of approximately 1500 Anishinaabe whose territory included both Manitoulin Island and the Bruce Peninsula. ${ }^{37}$ Bond Head spoke to the two groups separately, and, to those claiming Manitoulin Island, Bond Head decided to write his speech in English in the form of a memorandum, which, after Bond Head had read it aloud, was signed by the 16 Anishinaabe leaders and subsequently declared a treaty. ${ }^{38}$

The unusual origins of the 1836 Manitoulin treaty through Bond Head's own transcription of his speech into a treaty versus formal treaty negotiations, resulted in a

36 For more on the wampum treaty at Niagara in 1764, see John Borrows, 'Wampum at Niagara: The Royal Proclamation, Canadian Legal History, and Self-government' in Michael Asch (ed), Aboriginal and Treaty Rights in Canada: Essays on Law, Equality and Respect for Difference (University of British Columbia Press 1997) 155-72.

37 Surtees (n 34) 8.

38 Ibid. 
questionable form of land agreement. ${ }^{39}$ Seeking to sustain his plan to move the Anishinaabe on to the island and make way for further settlement, Bond Head leans on yet more expressions of performance. In correspondence to Lord Glenelg, Bond Head relies on both the exchange of wampum at the signing and that the entire performance from speech to signing was witnessed by representatives of the church and Crown. ${ }^{40}$

In relation to the painted drum, we rejected the well-worn classification of ourselves as active subjects and the items we interact with as passive objects in favour of a more distributed account of agency. Moving away from thinking of ourselves as makers distanced from inanimate objects to an approach that interrogates what this thing is 'for' or what does this (treaty) 'want' allows us to reconsider objects and our relationships to them. We noted that such an approach resonates in Anishinaabe culture, in which some objects have 'agency' and relation to a particular individual, family or community, and/or their particular origin or use. ${ }^{41}$ It shouldn't be surprising then that, in our engagement with the treaty, we found that it 'wanted' to be read out loud. The document originated in speech and lends itself to aural comprehension.

We can speculate that, as a well-trained legal officer of the British empire, Commissioner Bond Head had a deep respect for the ceremonies and trappings of legal authority. In his dealings with the Anishinaabe of Manitoulin, his conduct reflected that particular understanding of the role of an officer of the law. Through speech, text, parchment dressed with ribbon and wax, gift exchange and witnessing he re-formed a (British/imperial) 'sense-scape'. His was a performance of British legal authority on Anishinaabe territory, which, according to his worldview, was what allowed him to lawfully realise his (and the Crown's) land acquisition objectives for Upper Canada. As is clear from our earlier discussion, this performance would not have resonated with the Anishinaabe signatories in the same way, which is one explanation for the legal contestation over that particular territory that has lasted until the present day.

\section{Putting the drum and the treaty into conversation}

The treaty and drum are contemporaries. They are participants in an ongoing process of negotiating relationships between people and territory in the Manitoulin area. When we consider them together, their potential shifts. The way we feel about them evolves. Their juxtaposition calls upon us to reclassify both treaty and drum by suspending underlying assumptions of order that led to their disparate treatments as law and artefact, respectively. Reading the treaty and drum together points us in the direction of a different kind of relationality. They demonstrate that there is more than one way to perform and derive meaning from law.

The treaty is the transcribed text of a speech. The normative authority that is attributed to it does not derive, in the way it is assumed to, from the historical facts of its production. There were no formal treaty negotiations between the Anishinaabe and Bond Head as the appointed treaty commissioner. The treaty's authority, seen in this context, rests on its performance. By Bond Head's own admission, initially the treaty was not properly made, but its assertion through pen, ink, paper, ribbon, wax, wampum and witness proved sufficient to retroactively authorise its claim. Though the treaty itself has been in storage for many years, these elements continue to sustain the document's claim

39 Bond Head admitted the unusual pathway from speech to treaty in a letter to Glenelg. See, IUP at 351, Bond Head to Glenelg, no 31, 20 August 1836.

40 Ibid.

41 Matthews (n 26). For good insight relating to agency of objects in Anishinaabe culture, see Simpson (n 3). 
to 'legal authority' through its attributed status as a historical treaty (and not a transcription of a speech, for example), as well as Canada's assertions of continuing authority over the same territory, despite the fact that the Anishinaabe have continuously contested its meaning. In contrast, classifying the drum, which too can be read and sounded, as merely a cultural artefact mutes its agency and removes it from the realm of law and legal authority. Like the treaty, the drum's claim to authority resonates with those who are trained to comprehend it. Each object speaks the language of its communities' law and, thus, facilitates the assertion of legal authority through both visual and aural means. Both objects are products of intersocietal entanglements, yet their classification has resulted in vastly different readings.

One underlying difference between the treatment of the drum and the treaty document is embedded in assumptions about property, what it is, and how it might be asserted. From the British/Canadian perspective, the treaty claims lands and resources to be possessed and governed, while the drum is an artefact to be owned and displayed.

One effect of the Euro-American division between persons and things is to promote property rights (between persons with respect to things) as the paradigmatic exemplification of ownership - so that when one talks of ownership one implies that rights are being exercised over (in relation to) some 'thing' or other. The more entities approximate to things, the more legitimate ownership appears. ${ }^{42}$

Our engagement with these objects as artefacts reveals the way in which the British/Canadian perspective frames Manitoulin Island as land available for appropriation and possession and the drum as a cultural artefact, without authority or agency. As a consequence, the land is appropriated, while the drum is muffled and removed, allowing the treaty to speak loudly and authoritatively as law. Through the lens of British/Canadian law, there is an elevation of the treaty and attempted erasure of the drum's agency and, by extension, of the Anishinaabe cosmology and worldview that the drum embodies. This one-sided approach falsely inflates the power of the Crown to endow it with legal meaning and authority and overlooks completely the sources and authority of Anishinaabe law.

Classifying an object of law, such as the Manitoulin Island drum, as an artefact and placing it in a museum is an act that orders the world exclusively within the Crown's vision. Yet, as if in resistance to this ordering, the drum sits silently in the British Museum as though waiting to be sounded again; inviting reflection upon what extraordinary objects are sometimes created through intersocietal engagement. And, as the imagery on the drum boldly declares, transformation can indeed be beautiful.

We have posited that both the treaty and the drum are intersocietal legal objects, that is, objects that bear the marks and mark the coming together of the settler and indigenous societies in a particular place and time. We have argued, in addition, that this equivalency has been obscured - while the drum has been silenced and isolated from the communities of knowledge to which it speaks and, in turn, gives voice to, and the hand and the voice of Sir Bond Head embodied in the handwritten document have been amplified by the forms and presumptions of colonial law-making. The drum speaks to law but has been silenced, while the treaty continues to amplify the assertion of colonial authority. By placing the drum and treaty in conversation, we seek to illustrate that both are legible as legal objects in different legal cultures. We hope to hear more from the drum and less from the treaty. 
We have also suggested that a reading that sets these two objects alongside each other might be instructive for those who are seeking to engage with law, beyond a reading of text, to interrogate form and agency. Though we have offered preliminary inquiry, the question lingers: how might one engage with both the painted drum and the handwritten treaty respectfully and lawfully according to British and Anishinaabe legal orders? 